\title{
Recent advances in preventing neurodegenerative diseases
}

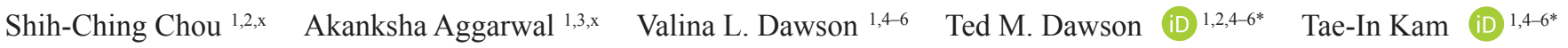 \\ ${ }^{1}$ Neuroregeneration and Stem Cell Programs, Institute for Cell Engineering, 733 North Broadway, Johns Hopkins University School of Medicine, Baltimore, MD \\ 21205, USA \\ ${ }^{2}$ Department of Pharmacology and Molecular Sciences, 725 North Wolfe St., Johns Hopkins University School of Medicine, Baltimore, MD 21205, USA \\ ${ }^{3}$ Department of Biological Chemistry, 725 North Wolfe St., Johns Hopkins University School of Medicine, Baltimore, MD 21205, USA \\ ${ }^{4}$ Department of Neurology, 725 North Wolfe St., Johns Hopkins University School of Medicine, Baltimore, MD 21205, USA \\ ${ }^{5}$ Adrienne Helis Malvin Medical Research Foundation, 228 St. Charles Avenue, New Orleans, LA 70130-2685, USA \\ ${ }^{6}$ Diana Helis Henry Medical Research Foundation, 228 St. Charles Avenue, New Orleans, LA 70130-2685, USA
}

${ }^{x}$ These authors contributed equally

\begin{abstract}
The worldwide health-care burden of neurodegenerative diseases is on the rise - a crisis created through a combination of increased caseload and lack of effective treatments. The limitations of pharmacotherapy in these disorders have led to an urgent shift toward research and clinical trials for the development of novel compounds, interventions, and methods that target shared features across the spectrum of neurodegenerative diseases. Research targets include neuronal cell death, mitochondrial dysfunction, protein aggregation, and neuroinflammation. In the past few years, there has been a growth in understanding of the pathophysiologic mechanisms of neurodegenerative disorders such as Alzheimer's disease, Parkinson's disease, amyotrophic lateral sclerosis, multiple sclerosis, and Huntington's disease. This increase in knowledge has led to the discovery of numerous novel neuroprotective therapeutic targets. In this context, we reviewed and summarized recent advancements in neuroprotective strategies in neurodegenerative diseases.
\end{abstract}

\section{Peer Review}

The peer reviewers who approve this article are:

1. Yingfei Wang, Department of Pathology, UT Southwestern Medical Center, Dallas, TX, USA; Department of Neurology, UT Southwestern Medical Center, Dallas, TX, USA

Competing interests: No competing interests were disclosed.

2. P Hemachandra Reddy, Department of Internal Medicine, Texas Tech University Health Sciences Center, Lubbock, TX, USA; Neuroscience \& Pharmacology, Texas Tech University Health Sciences Center, Lubbock, TX, USA; Neurology, Departments of School of Medicine, Texas Tech University Health Sciences Center, Lubbock, TX, USA; Public Health Department of Graduate School of Biomedical Sciences, Texas Tech University Health Sciences Center, Lubbock, TX, USA; Department of Speech, Language and Hearing Sciences, School Health Professions, Texas Tech University Health Sciences Center, Lubbock, TX, USA

Competing interests: No competing interests were disclosed. 
*Corresponding author: Tae-In Kam (tkam1@jhmi.edu); Ted M. Dawson (tdawson@jhmi.edu)

Competing interests: TMD and VLD own stock options in Inhibikase Therapeutics Inc., are founders of and hold an ownership equity interest in Valted LLC, are inventors of technology of Neuraly Inc. that has been optioned from Johns Hopkins University, and are founders of and hold shares of stock options and equity in Neuraly Inc., which is now a subsidiary of D\&D Pharmatech. TMD and his spouse hold shares of stock options and equity in D\&D Pharmatech and are founders of and hold equity in Valted Seq Inc. TMD is the Leonard and Madlyn Abramson Professor in Neurodegenerative Diseases. These arrangements have been reviewed and approved by Johns Hopkins University in accordance with its conflict-of-interest policies. The other authors declare that they have no competing interests.

Grant information: T-IK is supported by Diana Helis Henry Medical Research Foundation and grants from the National Institutes of Health's National Institute of Neurological Disorders and Stroke (NS123456) and the Maryland Stem Cell Research Fund (2020-MSCRFL-5427). This work was also supported by the JPB Foundation, grants from the National Institutes of Health's National Institute of Neurological Disorders and Stroke (NS38377, R37NS067525, and NIA RF1AG059686), and an Alzheimer's Association Zenith Fellows Award to TMD.

The funders had no role in study design, data collection and analysis, decision to publish, or preparation of the manuscript.

Copyright: $(1021$ Dawson TM et al. This is an open access article distributed under the terms of the Creative Commons Attribution License, which permits unrestricted use, distribution, and reproduction in any medium, provided the original work is properly cited.

How to cite this article: Chou SC, Aggarwal A, Dawson VL, Dawson TM and Kam TI. Recent advances in preventing neurodegenerative diseases. Faculty Reviews 2021 10:(81) https://doi.org/10.12703/r/10-81

Published: 01 Dec 2021, Faculty Reviews 10:(81) https://doi.org/10.12703/r/10-81 


\section{Introduction}

Neurodegenerative diseases include a broad range of disorders characterized by neuronal injury or degeneration leading to neurological impairment. These diseases include Alzheimer's disease (AD), Parkinson's disease (PD), multiple sclerosis (MS), amyotrophic lateral sclerosis (ALS), and Huntington's disease (HD) that manifest in millions of people worldwide every year. The common characteristic of these disorders is neuronal loss or impairment resulting in chronic deterioration in memory, locomotor difficulties, psychological impairment, and cognitive defects. Researchers are pursuing a collaborative approach to preserve the function and networks of neural tissues before damage occurs. This neuroprotective approach focuses on the development of strategies that prevent or arrest various types of neuronal cell death mechanisms such as oxidative stress, mitochondrial dysfunction, neuroinflammation, protein aggregation, and defective autophagy, thus limiting disease progression. The purpose of this review is to summarize recent developments in neuroprotective strategies for neurodegenerative diseases.

\section{Prevention of cell-autonomous neurodegeneration}

Cells employ a variety of self-repair mechanisms to maintain and restore physiological homeostasis. When a cell exceeds the ability to overcome stress or damage, intracellular homeostasis collapses and induces a series of cell death signaling cascades. Over the last few years, studies have shown that the apoptotic cell death is not the only pathway dominating neuronal loss in neurodegenerative diseases. Among them, poly (ADP-ribose) (PAR)-dependent cell death, or parthanatos, has been established as being responsible for neuronal loss in a variety of neurological diseases, including $\mathrm{AD}, \mathrm{PD}, \mathrm{ALS}$, and $\mathrm{HD}^{1}$. PARP1 plays a multi-functional role in a variety of cellular processes such as DNA repair pathways, genomic stability, and inflammation ${ }^{2}$. Oxidative stress or nitric oxide production damages DNA, resulting in excessive intracellular PAR accumulation due to PARP1 activation ${ }^{1}$. Several cellular processes result in parthanatos, including PARP1 overactivation, release of apoptosis-inducing factor (AIF) from mitochondria, and co-translocation of AIF and macrophage migration inhibitory factor (MIF) into the nucleus, leading to DNA fragmentation and cell death ${ }^{2-4}$.

Overactivation of PARP1 and PAR accumulation have been observed in the brains of AD patients and mouse models ${ }^{5,6}$, and genetic or pharmacological inhibition of PARP1 protected neurons in $\mathrm{AD}$ models ${ }^{7-9}$. Recent studies have also indicated that cells of cognitively impaired patients are more susceptible to $\mathrm{H}_{2} \mathrm{O}_{2}$-induced parthanatos ${ }^{10}$, tissue acidosis-induced amplification of neuronal parthanatos ${ }^{11}$, and robust internal inflammation response following ischemic injuries ${ }^{12,13}$. Moreover, amyloid $\beta$ (A $\beta)$ causes hippocampal neurotoxicity by inducing oxidative stress-mediated PARP1 activation, which leads to transient receptor potential melastatin-related 2 (TRPM2) activation and $\mathrm{Ca}^{2+}$ influx and mitochondrial dysfunction ${ }^{14}$. Notably, studies have shown that neurons are protected by PARP1 inhibition, which implies that PARP1 inhibition may have therapeutic value for the treatment of AD.

Recent discoveries in PD models show more direct evidence that parthanatos is the main cell death pathway in pathologic $\alpha$-synuclein neurodegeneration. In this pathway, PAR is a key mediator, promoting $\alpha$-synuclein toxicity and fibril transmission, exacerbating neurotoxicity in a feed-forward loop ${ }^{15}$. Interaction between PAR and $\alpha$-synuclein was also found in post-mortem brains of patients with $\mathrm{PD}^{16-18}$. In addition, inhibition of PARP1 may promote $\alpha$-synuclein autophagy via transcription factor EB-mediated signaling and downregulation of mammalian target of rapamycin (mTOR) signaling, which lessened cytotoxicity of $\alpha$-synuclein aggregation ${ }^{17}$. Genetic depletion of PARP1 and oral administration of PARP1 inhibitor prevented neurodegeneration and improved motor ability in both sporadic and genetic mouse models of $\mathrm{PD}^{15,17}$. Moreover, PAR levels were increased in the cerebral spinal fluid and brains of patients with $\mathrm{PD}^{15}$, suggesting that PARP1 could be a theragnostic biomarker and a disease-modifying therapeutic target in $\mathrm{PD}^{19}$.

In the ALS brain, expression of PARP1 is increased and localized to a subset of TAR DNA-binding protein 43 (TDP43) inclusions, primary cytological features of ALS ${ }^{20,21}$. Additionally, PAR favors the accumulation and aggregation of hnRNP A1 and TDP43 in stress granules, as observed in patients with $\mathrm{ALS}^{22,23}$. Elevated PARP activity is observed in the motor neurons of the ALS spinal cord, and inhibition of PARP mitigates hnRNP A1- or TDP43-mediated neurotoxicity in cell and drosophila models of $\mathrm{ALS}^{22,24}$.

In $\mathrm{HD}$, elongated polyglutamine (polyQ) is responsible for huntingtin (htt) protein aggregation and is associated with neuronal inclusions and toxicity ${ }^{25}$. Recently, several co-morbid pathogenic processes were identified in the caudate nucleus of HD brains. The accumulation of damaged DNA, increased PARP1 expression, and localization of htt protein to the DNA damage site were found in conjunction with only weak caspase 3 activation ${ }^{26}$. This finding suggests a pathologic relationship between caspase-independent parthanatos and HD. Moreover, the treatment of PARP1 inhibitor to HD model R6/2 mutant mice showed longer survival and less neuropathologic dysfunction ${ }^{27,28}$. Although these findings suggest a neuroprotective effect of PARP1 in HD, further studies are required to determine the direct relationship of parthanatos to HD.

Dysregulation of PARP1 activation and increased PAR levels contribute to the pathogenesis of various neurodegenerative diseases by promoting protein aggregation and parthanatos. Thus, neuroprotective strategies aimed to inhibit PARP1 activation may have therapeutic potential in those disorders. Many well-characterized PARP inhibitors in clinical use have yet to be tested for use in neurodegenerative disease ${ }^{29}$. These should be considered for neuroprotective treatment for neurological diseases. 


\section{Prevention of non-cell-autonomous neurodegeneration}

Glial cells play a central role in neuronal support by maintaining homeostasis, nutrient transportation, and neurogenesis in healthy brains ${ }^{30}$. Importantly, a growing body of research has shown that dysfunctional non-neuronal cells such as microglia and astrocytes directly contribute to neurodegeneration and cell death (so-called non-cell-autonomous neurodegeneration) in a variety of neurodegenerative diseases.

In the brain, microglia are the resident macrophages and primary immune cells. Therefore, they play an important role in neuronal disease. Recent single-cell RNA analysis of central nervous system (CNS) immune cells in AD models discovered a pro-inflammatory signature present in $\mathrm{A} \beta$ plaque-associated microglia, also known as disease-associated microglia (DAM), which might play both a toxic and a protective role in $\mathrm{AD}^{31-34}$. DAMs have also been observed in other neurodegenerative conditions, including aging, ALS, and frontotemporal dementia $(\mathrm{FTD})^{33}$. Reactive microglia are presented in post-mortem $\mathrm{AD}$ brains and have been shown to promote synaptic loss and neuroinflammation in $\mathrm{AD}^{35,36}$. Emerging studies suggest that dysregulation of neuroinflammation is modulated by TREM2 and ApoE, which eventually contribute to synaptic loss in multiple $\mathrm{AD}$ models $\mathrm{s}^{33,37-40}$. Additionally, inefficient microglia clearance of pathologic proteins plays an adverse role in the spread of tau in tauopathy and $\mathrm{AD}^{41}$. Polarization of microglia toward a neuroprotective M2 type improves neurological deficits in post-ischemic stroke through activation of AMP-activated protein kinase (AMPK) and nuclear factor erythroid 2-related factor 2 (Nrf2) or peroxisome proliferator-activated receptor gamma coactivator $1 \alpha(\mathrm{PGC}-1 \alpha)$ neuroprotective pathways ${ }^{42,43}$. Many PD-related genes, including $\alpha$-synuclein, PINK1, and parkin, are expressed in glial cells. Mutated gene products are involved in microglial dysfunction during PD pathogenesis ${ }^{44}$. Also, microglia have been found to modulate the transmission of $\alpha$-synuclein in the brain ${ }^{45,46}$. Recent spatial transcriptomics of ALS patients and mouse models revealed that changes in microglial gene expression preceded and contributed to motor neuron loss ${ }^{47}$. Accordingly, pharmacological blockage of neuregulin (NRG) receptors present on microglia (associated with ALS disease progression) has been shown to slow disease advancement in an SOD1-ALS mouse model ${ }^{48}$. In summary, microglia are thought to have both beneficial and detrimental functions in neurodegenerative diseases. Thus, induction of DAM or homeostatic microglia signature and subsequent prevention of neurotoxic microglia signature could be promising therapeutic strategies for neuroprotection in neurodegenerative diseases, but the factors associated with heterogenous microglial phenotype will need to be defined in more detail.

Astrocytes are the most abundant population of glial cells in the CNS and perform a broad range of homeostatic functions. Consequently, it is not surprising that the loss of normal astrocyte function is involved in the pathogenesis of neurodegenerative diseases. A 2017 study showed that activated microglia induce the formation of neurotoxic reactive astrocytes by secreting interleukin $1 \alpha$ (IL- $1 \alpha$ ), tumor necrosis factor $\alpha(\mathrm{TNF}-\alpha)$, and $\mathrm{C} 1 \mathrm{q}^{49}$. These reactive astrocytes were found in post-mortem brains of human neurodegenerative diseases, including $\mathrm{AD}, \mathrm{PD}, \mathrm{ALS}$, and $\mathrm{HD}^{49}$. The contribution of reactive astrocytes to neurodegeneration has been determined in disease models of $\mathrm{PD}^{50}, \mathrm{AD}^{51}, \mathrm{ALS}^{52}$, and $\mathrm{MS}^{53}$. The presence of reactive astrocytes in numerous disease models creates a prime opportunity for development of neuroprotective therapies that can be shared across multiple neurodegenerative diseases. For example, direct prevention of microglia-mediated naïve astrocyte transformation into reactive astrocytes by Glucagon-like peptide 1 (GLP1) receptor agonist improves behavioral deficits and neurodegeneration in pathologic $\alpha$-synuclein mouse models of $\mathrm{PD}^{50}$. This restorative intervention could be applied to other neurodegenerative disease models. GLP1 receptor agonists are protective in $\mathrm{AD}$ mouse models ${ }^{54}$. Additionally, in mouse models for $\mathrm{PD}$, activation of receptor CD44 (expressed on astrocytes) helped reduce nuclear factor kappa B (NFkB) activation and inflammatory response ${ }^{55}$. In another study, dopaminergic neurons produced high levels of prokineticin 2 (PK2) protein ${ }^{56}$. Astrocytes have PK2 receptors; upon ligand-receptor binding, there is a reduction in pro-inflammatory factors and an increase in several antioxidant genes $^{56}$. Genetic depletion of reactive astrocytes markedly extended survival in ALS mouse models ${ }^{57}$. Inhibition of astrocyte reactivity by modulating the JAK2-STAT3 pathway reduced amyloid deposition and synaptic and behavioral deficits in an $\mathrm{AD}$ mouse model ${ }^{58}$. In ischemic stroke mouse models, knockout of glutamate-releasing SWELL1 channel present in astrocytes decreased excitotoxicity ${ }^{59}$. More recently, however, it has been identified that the phenotype diversity of astrocytes is observed in brains of neurodegenerative diseases and extends beyond the A1 and A2 phenotypes ${ }^{60-65}$. Thus, further investigation is needed to better understand the molecular mechanisms of reactive astrocytes and their specific role within different neurodegenerative pathologies, especially how neurotoxic signals transduce and are shared across multiple neurodegenerative conditions.

\section{Conclusions}

Neurodegenerative diseases are the result of a number of factors, including genetic mutations, neuronal cell death, mitochondrial dysfunction, protein aggregation, flawed protein recycling, and innate immune responses due to activation in glial cells. Thus, neuroprotection from cell-autonomous neurodegeneration could be achieved by directly targeting degenerating neurons and from non-cell-autonomous neurodegeneration by targeting their neighboring glial cells (Figure 1). Thus, a multifaceted approach targeting both cell-autonomous and non-cell-autonomous mechanisms may be required to prevent or slow neurodegeneration. During the previous decade, consistent and focused studies have revealed the causal factors in neurodegenerative diseases. Understanding the molecular mechanisms of neurodegeneration is an essential step forward in the development of novel neuroprotective therapies. The last couple of years have seen advancements in both research 


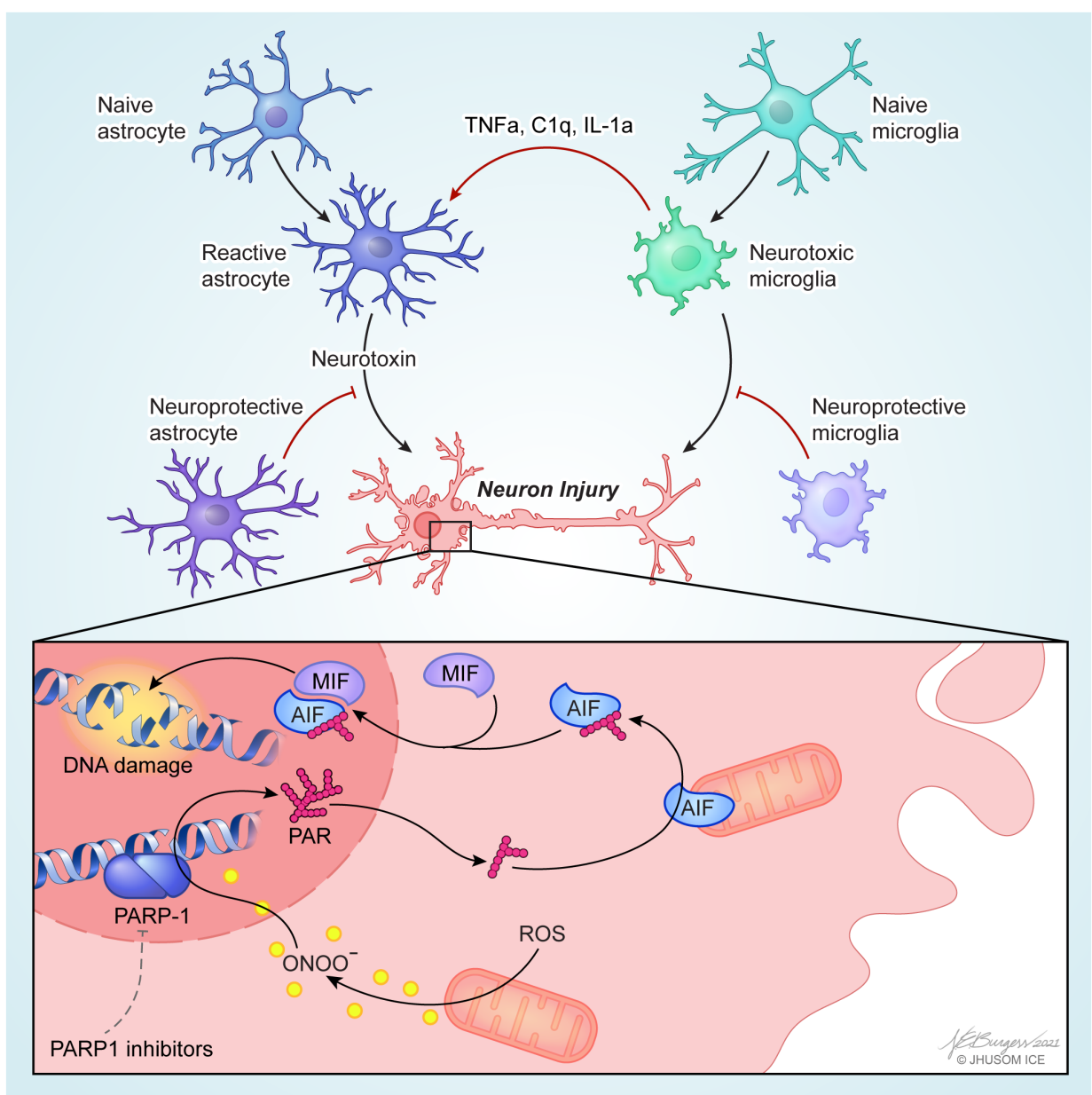

Figure 1. Cell-autonomous and non-cell-autonomous neurodegeneration. PARP1-dependent cell-autonomous mechanisms of neurodegeneration (bottom). Neuron injury stressors such as an oxidative stress or aggregated proteins activate nitric oxide synthase that produces nitric oxide and then peroxynitrite $\left(\mathrm{ONOO}^{-}\right)$, resulting in overactivation of PARP1. Accumulated poly (ADP-ribose) (PAR) polymers synthesized by overactivated PARP1 translocate from the nucleus to the cytoplasm and mitochondria, where it binds to and induces mitochondrial release of apoptosis-inducing factor (AIF). AlF-bound macrophage migration-inducing factor (MIF) nuclease translocates into the nucleus, where MIF cleaves genomic DNA into large-scale fragments, causing cell death. Inhibition of PARP1 can protect neurons in a variety of neurodegenerative diseases (see 'Prevention of cell-autonomous neurodegeneration' section). Non-cell-autonomous mechanisms of neurodegeneration mediated by microglia or astrocytes (top). Induction of disease-associated microglia or homeostatic microglia and subsequent prevention of neurotoxic microglia could be promising neuroprotection strategies in neurodegenerative diseases. Alternatively, activated microglia induces the formation of neurotoxic reactive astrocytes by secreting interleukin $1 \alpha$ (IL-1 $\alpha$ ), tumor necrosis factor $\alpha$ (TNF- $\alpha$ ), and C1q. Reactive astrocyte-targeted neuroprotection could be achieved by microglial inhibition of formation of neurotoxic reactive astrocytes and induction of neuroprotective astrocytes. PARP, poly (ADP-ribose) polymerase; ROS, reactive oxygen species.

and clinical understanding of potential novel neuroprotective therapeutics. Owing to tremendous effort, these therapies have progressed beyond the lab and into the clinical testing stage. Despite this progress, therapies to prevent or decrease disease progression and restore neuronal function remain a challenge and an ongoing focus in both research and clinical practice. Thus, further investigation into the neurodegenerative pathways and the identification and development of neuroprotective agents are needed to develop promising disease-modifying therapeutic approaches for the treatment of neurodegenerative disease.

\section{Acknowledgments}

The authors acknowledge the joint participation by the Adrienne Helis Malvin Medical Research Foundation and the Diana Helis Henry Medical Research Foundation through its direct engagement in the continuous active conduct of medical research in conjunction with the Johns Hopkins Hospital and the Johns Hopkins University School of Medicine and the Foundation's Parkinson's Disease Programs M-2017, H-2018, and M-2019. We thank Noelle Burgess (Johns Hopkins University) for assistance with the illustrations in Figure 1. 
1. Park H, Kam TI, Dawson TM, et al:: Poly (ADP-ribose) (PAR)-dependent cell death in neurodegenerative diseases. Int Rev Cell Mol Biol. 2020; 353: 1-29. PubMed Abstract | Publisher Full Text

2. Wang Y, Kim NS, Haince JF, et al:: Poly(ADP-ribose) (PAR) binding to apoptosis-inducing factor is critical for PAR polymerase-1-dependent cell death (parthanatos). Sci Signal. 2011; 4(167): ra20. PubMed Abstract | Publisher Full Text | Free Full Text

3. Wang Y, An R, Umanah GK, et al.: A nuclease that mediates cell death induced by DNA damage and poly(ADP-ribose) polymerase-1. Science. 2016; 354(6308): aad6872.

PubMed Abstract | Publisher Full Text | Free Full Text | Faculty Opinions Recommendation

4. Wang Y, Kim NS, Li X, et al.: Calpain activation is not required for AIF translocation in PARP-1-dependent cell death (parthanatos). J Neurochem. 2009; 110(2): 687-96.

PubMed Abstract | Publisher Full Text | Free Full Text

5. Love S, Barber R, Wilcock GK: Increased poly(ADP-ribosyl)ation of nuclear proteins in Alzheimer's disease. Brain. 1999; 122(Pt 2): 247-53. PubMed Abstract | Publisher Full Text

6. Martire S, Fuso A, Rotili D, et al.: PARP-1 modulates amyloid beta peptideinduced neuronal damage. PLoS One. 2013; 8(9): e72169. PubMed Abstract | Publisher Full Text | Free Full Text

7. Abeti R, Abramov AY, Duchen MR: Beta-amyloid activates PARP causing astrocytic metabolic failure and neuronal death. Brain. 2011; 134(Pt 6): 1658-72.

PubMed Abstract | Publisher Full Text

8. Kauppinen TM, Suh SW, Higashi Y, et al.: Poly(ADP-ribose)polymerase-1 modulates microglial responses to amyloid $\boldsymbol{\beta}$. J Neuroinflammation. 2011; 8: 152.

PubMed Abstract | Publisher Full Text | Free Full Text

9. Turunc Bayrakdar E, Uyanikgil $Y$, Kanit $L$, et al.: Nicotinamide treatment reduces the levels of oxidative stress, apoptosis, and PARP-1 activity in A $\beta(1-42)$ induced rat model of Alzheimer's disease. Free Radic Res. 2014; 48(2): 146-58. PubMed Abstract | Publisher Full Text

10. Salech F, Ponce DP, SanMartín CD, et al:: PARP-1 and p53 Regulate the Increased Susceptibility to Oxidative Death of Lymphocytes from $\mathrm{MCl}$ and $\mathrm{AD}$ Patients. Front Aging Neurosci. 2017; 9: 310. PubMed Abstract | Publisher Full Text | Free Full Text

11. Zhang J, Li X, Kwansa H, et al:: Augmentation of poly(ADP-ribose) polymerasedependent neuronal cell death by acidosis. J Cereb Blood Flow Metab. 2017 37(6): 1982-93.

PubMed Abstract | Publisher Full Text | Free Full Text

12. Jang HR, Lee K, Jeon J, et al.: Poly (ADP-Ribose) Polymerase Inhibitor Treatment as a Novel Therapy Attenuating Renal Ischemia-Reperfusion Injury. Front Immunol. 2020; 11: 564288.

PubMed Abstract | Publisher Full Text | Free Full Text |

Faculty Opinions Recommendation

13. Li X, Ling $\mathrm{Y}, \mathrm{Cao} Z$, et al:: Targeting intestinal epithelial cell-programmed necrosis alleviates tissue injury after intestinal ischemia/reperfusion in rats. J Surg Res. 2018; 225: 108-17.

PubMed Abstract | Publisher Full Text

14. Li X, Jiang LH: Multiple molecular mechanisms form a positive feedback loop driving amyloid $\beta 42$ peptide-induced neurotoxicity via activation of the TRPM2 channel in hippocampal neurons. Cell Death Dis. 2018; 9(2): 195. PubMed Abstract | Publisher Full Text | Free Full Text

15. CKam TI, Mao X, Park H, et al.: Poly(ADP-ribose) drives pathologic $\alpha$ synuclein neurodegeneration in Parkinson's disease. Science. 2018; 362(6414): eaat8407.

PubMed Abstract | Publisher Full Text | Free Full Text |

Faculty Opinions Recommendation

16. CPuentes LN, Lengyel-Zhand Z, Lee JY, et al.: Poly (ADP-ribose) Interacts With Phosphorylated $\alpha$-Synuclein in Post Mortem PD Samples. Front Aging Neurosci. 2021; 13: 704041 .

PubMed Abstract | Publisher Full Text | Free Full Text | Faculty Opinions Recommendation

17. Mao K, Chen J, Yu H, et al.: Poly (ADP-ribose) polymerase 1 inhibition prevents neurodegeneration and promotes $\alpha$-synuclein degradation via transcription factor EB-dependent autophagy in mutant $\alpha$-synucleinA53T model of Parkinson's disease. Aging Cell. 2020; 19(6): e13163. PubMed Abstract | Publisher Full Text | Free Full Tex

18. Salemi M, Mazzetti S, de Leonardis M, et al:: Poly (ADP-ribose) polymerase 1 and Parkinson's disease: A study in post-mortem human brain. Neurochem Int. 2021; 144: 104978

PubMed Abstract | Publisher Full Text | Faculty Opinions Recommendation

19. Olsen AL, Feany MB: PARP Inhibitors and Parkinson's Disease. N Engl J Med. 2019; 380(5): 492-4.

PubMed Abstract | Publisher Full Text
20. Kim SH, Engelhardt JI, Henkel JS, et al.: Widespread increased expression of the DNA repair enzyme PARP in brain in ALS. Neurology. 2004; 62(2): 319-22. PubMed Abstract | Publisher Full Text

21. McGurk L, Lee VM, Trojanowksi JQ, et al:: Poly-A binding protein-1 localization to a subset of TDP-43 inclusions in amyotrophic lateral sclerosis occurs more frequently in patients harboring an expansion in C9orf72. J Neuropathol Exp Neurol. 2014; 73(9): 837-45.

PubMed Abstract | Publisher Full Text | Free Full Text

22. D Duan Y, Du A, Gu J, et al.: PARylation regulates stress granule dynamics, phase separation, and neurotoxicity of disease-related RNA-binding proteins. Cell Res. 2019; 29(3): 233-47.

PubMed Abstract | Publisher Full Text | Free Full Text | Faculty Opinions Recommendation

23. N McGurk L, Gomes E, Guo L, et al.: Poly(ADP-Ribose) Prevents Pathological Phase Separation of TDP-43 by Promoting Liquid Demixing and Stress Granule Localization. Mol Cell. 2018; 71(5): 703-717.e9. PubMed Abstract | Publisher Full Text | Free Full Text | Faculty Opinions Recommendation

24. McGurk L, Mojsilovic-Petrovic J, van Deerlin VM, et al:: Nuclear poly(ADPribose) activity is a therapeutic target in amyotrophic lateral sclerosis. Acta Neuropathol Commun. 2018; 6(1): 84 .

PubMed Abstract | Publisher Full Text | Free Full Text

25. Williams AJ, Paulson HL: Polyglutamine neurodegeneration: Protein misfolding revisited. Trends Neurosci. 2008; 31(10): 521-8.

PubMed Abstract | Publisher Full Text | Free Full Text

26. Maiuri T, Mocle AJ, Hung CL, et al.: Huntingtin is a scaffolding protein in the ATM oxidative DNA damage response complex. Hum Mol Genet. 2017; 26(2): 395-406.

PubMed Abstract | Publisher Full Text

27. Cardinale A, Paldino E, Giampà C, et al:: PARP-1 Inhibition Is Neuroprotective in the R6/2 Mouse Model of Huntington's Disease. PLoS One. 2015; 10(8): e0134482.

PubMed Abstract | Publisher Full Text | Free Full Text

28. Paldino E, Cardinale A, D'Angelo V, et al:: Selective Sparing of Striatal Interneurons after Poly (ADP-Ribose) Polymerase 1 Inhibition in the R6/2 Mouse Model of Huntington's Disease. Front Neuroanat. 2017; 11: 61. PubMed Abstract | Publisher Full Text | Free Full Text

29. Berger NA, Besson VC, Boulares AH, et al:: Opportunities for the repurposing of PARP inhibitors for the therapy of non-oncological diseases. Br J Pharmacol. 2018; 175(2): 192-222.

PubMed Abstract | Publisher Full Text | Free Full Text

30. Wang G, Zhou Y, Wang $Y$, et al.: Age-Associated Dopaminergic Neuron Loss and Midbrain Glia Cell Phenotypic Polarization. Neuroscience. 2019; 415 89-96.

PubMed Abstract | Publisher Full Text | Faculty Opinions Recommendation

31. Ajami B, Samusik N, Wieghofer $P$, et al.: Single-cell mass cytometry reveals distinct populations of brain myeloid cells in mouse neuroinflammation and neurodegeneration models. Nat Neurosci. 2018; 21(4): 541-51. PubMed Abstract | Publisher Full Text

32. Friedman BA, Srinivasan K, Ayalon G, et al: Diverse Brain Myeloid Expression Profiles Reveal Distinct Microglial Activation States and Aspects of Alzheimer's Disease Not Evident in Mouse Models. Cell Rep. 2018; 22(3) 832-47.

PubMed Abstract | Publisher Full Text

33. Keren-Shaul H, Spinrad A, Weiner A, et al:: A Unique Microglia Type Associated with Restricting Development of Alzheimer's Disease. Cell. 2017; 169(7): 1276-1290.e17.

PubMed Abstract | Publisher Full Text | Faculty Opinions Recommendation

34. Olah M, Patrick E, Villani AC, et al.: A transcriptomic atlas of aged human microglia. Nat Commun. 2018; 9(1): 539.

PubMed Abstract | Publisher Full Text | Free Full Text

35. Rajendran L, Paolicelli RC: Microglia-Mediated Synapse Loss in Alzheimer's Disease. J Neurosci. 2018; 38(12): 2911-9. PubMed Abstract | Publisher Full Text | Free Full Text

36. Vvan der Kant R, Goldstein LSB, Ossenkoppele R: Amyloid- $\beta$-independent regulators of tau pathology in Alzheimer disease. Nat Rev Neurosci. 2020; 21(1): 21-35

PubMed Abstract | Publisher Full Text | Faculty Opinions Recommendation

37. Dejanovic B, Huntley MA, de Mazière A, et al:: Changes in the Synaptic Proteome in Tauopathy and Rescue of Tau-Induced Synapse Loss by C1q Antibodies. Neuron. 2018; 100(6): 1322-1336.e7. PubMed Abstract | Publisher Full Text | Faculty Opinions Recommendation

38. - Gratuze M, Leyns CE, Sauerbeck AD, et al.: Impact of TREM2 ${ }^{\mathrm{R} 47 \mathrm{H}}$ variant on tau pathology-induced gliosis and neurodegeneration. J Clin Invest. 2020; 130(9): 4954-68

PubMed Abstract | Publisher Full Text | Free Full Text |

Faculty Opinions Recommendation 
39. Ulland TK, Song WM, Huang SCC, et al.: TREM2 Maintains Microglial Metabolic Fitness in Alzheimer's Disease. Cell. 2017; 170(4): 649-663.e13. PubMed Abstract | Publisher Full Text | Free Full Text

40. YYin C, Ackermann S, Ma Z, et al.: ApoE attenuates unresolvable inflammation by complex formation with activated C1q. Nat Med. 2019; 25(3): 496-506.

PubMed Abstract | Publisher Full Text | Free Full Text |

Faculty Opinions Recommendation

41. Hopp SC, Lin Y, Oakley D, et al.: The role of microglia in processing and spreading of bioactive tau seeds in Alzheimer's disease. J Neuroinflammation. 2018; 15(1): 269.

PubMed Abstract | Publisher Full Text | Free Full Text

42. Wang $Y$, Huang $Y, X u Y$, et al.: A Dual AMPK/Nrf2 Activator Reduces Brain Inflammation After Stroke by Enhancing Microglia M2 Polarization. Antioxid Redox Signal. 2018; 28(2): 141-63. PubMed Abstract | Publisher Full Text

43. Yang $\mathrm{X}, \mathrm{Xu}$ S, Qian $\mathrm{Y}$, et al.: Resveratrol regulates microglia M1/M2 polarization via PGC-1 $\alpha$ in conditions of neuroinflammatory injury. Brain Behav Immun. 2017; 64: 162-72.

PubMed Abstract | Publisher Full Text

44. Kam TI, Hinkle JT, Dawson TM, et al:: Microglia and astrocyte dysfunction in parkinson's disease. Neurobiol Dis. 2020; 144: 105028. PubMed Abstract | Publisher Full Text | Free Full Tex

45. George S, Rey NL, Tyson T, et al:: Microglia affect $\alpha$-synuclein cell-to-cell transfer in a mouse model of Parkinson's disease. Mol Neurodegener. 2019; 14(1): 34 .

PubMed Abstract | Publisher Full Text | Free Full Text

46. Xia Y, Zhang G, Han C, et al:: Microglia as modulators of exosomal alpha-synuclein transmission. Cell Death Dis. 2019; 10(3): 174. PubMed Abstract | Publisher Full Text | Free Full Text

47. Maniatis S, Äijö T, Vickovic S, et al:: Spatiotemporal dynamics of molecular pathology in amyotrophic lateral sclerosis. Science. 2019; 364(6435): 89-93. PubMed Abstract | Publisher Full Text

48. Liu J, Allender E, Wang J, et al:: Slowing disease progression in the SOD1 mouse model of ALS by blocking neuregulin-induced microglial activation. Neurobiol Dis. 2018; 111: 118-26. PubMed Abstract | Publisher Full Text

49. Liddelow SA, Guttenplan KA, Clarke LE, et al:: Neurotoxic reactive astrocytes are induced by activated microglia. Nature. 2017; 541(7638): 481-7. PubMed Abstract | Publisher Full Text | Free Full Text | Faculty Opinions Recommendation

50. Yun SP, Kam TI, Panicker N, et al.: Block of A1 astrocyte conversion by microglia is neuroprotective in models of Parkinson's disease. Nat Med. 2018; 24(7): 931-8. PubMed Abstract | Publisher Full Text | Free Full Text

51. S Shi Y, Yamada K, Liddelow SA, et al.: ApoE4 markedly exacerbates tau-mediated neurodegeneration in a mouse model of tauopathy. Nature. 2017; 549(7673): 523-7.

PubMed Abstract | Publisher Full Text | Free Full Text | Faculty Opinions Recommendation

52. Peng AYT, Agrawal I, Ho WY, et al.: Loss of TDP-43 in astrocytes leads to motor deficits by triggering A1-like reactive phenotype and triglial dysfunction. Proc Natl Acad Sci U S A. 2020; 117(46): 29101-12. PubMed Abstract | Publisher Full Text | Free Full Text | Faculty Opinions Recommendation
53. Jin J, Smith MD, Kersbergen CJ, et al:: Glial pathology and retinal neurotoxicity in the anterior visual pathway in experimental autoimmune encephalomyelitis. Acta Neuropathol Commun. 2019; 7(1): 125. PubMed Abstract | Publisher Full Text | Free Full Text

54. Park JS, Kam TI, Lee S, et al.: Blocking microglial activation of reactive astrocytes is neuroprotective in models of Alzheimer's disease. Acta Neuropathol Commun. 2021; 9(1): 78. PubMed Abstract | Publisher Full Text | Free Full Text

55. Neal ML, Boyle AM, Budge KM, et al:: The glycoprotein GPNMB attenuates astrocyte inflammatory responses through the CD44 receptor. J Neuroinflammation. 2018; 15(1): 73. PubMed Abstract | Publisher Full Text | Free Full Text

56. Neal M, Luo J, Harischandra DS, et al.: Prokineticin-2 promotes chemotaxis and alternative A2 reactivity of astrocytes. Glia. 2018; 66(10): 2137-57. PubMed Abstract | Publisher Full Text | Free Full Text

57. Guttenplan KA, Weigel MK, Adler DI, et al:: Knockout of reactive astrocyte activating factors slows disease progression in an ALS mouse model. Nat Commun. 2020; 11(1): 3753

PubMed Abstract | Publisher Full Text | Free Full Text |

Faculty Opinions Recommendation

58. Ceyzériat K, Ben Haim L, Denizot A, et al.: Modulation of astrocyte reactivity improves functional deficits in mouse models of Alzheimer's disease. Acta Neuropathol Commun. 2018; 6(1): 104 PubMed Abstract | Publisher Full Text | Free Full Text

59. N Yang J, Vitery MDC, Chen J, et al.: Glutamate-Releasing SWELL1 Channel in Astrocytes Modulates Synaptic Transmission and Promotes Brain Damage in Stroke. Neuron. 2019; 102(4): 813-827.e6. PubMed Abstract | Publisher Full Text | Free Full Text | Faculty Opinions Recommendation

60. Al-Dalahmah O, Sosunov AA, Shaik A, et al:: Single-nucleus RNA-seq identifies Huntington disease astrocyte states. Acta Neuropathol Commun. 2020; 8(1): 19

PubMed Abstract | Publisher Full Text | Free Full Text | Faculty Opinions Recommendation

61. Das S, Li Z, Noori A, et al.: Meta-analysis of mouse transcriptomic studies supports a context-dependent astrocyte reaction in acute CNS injury versus neurodegeneration. J Neuroinflammation. 2020; 17(1): 227. PubMed Abstract | Publisher Full Text | Free Full Text | Faculty Opinions Recommendation

62. Diaz-Castro B, Gangwani MR, Yu X, et al:: Astrocyte molecular signatures in Huntington's disease. Sci Transl Med. 2019; 11(514): eaaw8546. PubMed Abstract | Publisher Full Text

63. Grubman A, Chew G, Ouyang JF, et al:: A single-cell atlas of entorhinal cortex from individuals with Alzheimer's disease reveals cell-type-specific gene expression regulation. Nat Neurosci. 2019; 22(12): 2087-97. PubMed Abstract | Publisher Full Text

64. Wheeler MA, Clark IC, Tjon EC, et al.: MAFG-driven astrocytes promote CNS inflammation. Nature. 2020; 578(7796): 593-9. PubMed Abstract | Publisher Full Text | Free Full Text | Faculty Opinions Recommendation

65. Zhou Y, Song WM, Andhey PS, et al:: Human and mouse single-nucleus transcriptomics reveal TREM2-dependent and TREM2-independent cellular responses in Alzheimer's disease. Nat Med. 2020; 26(1): 131-42. PubMed Abstract | Publisher Full Text | Free Full Text |

Faculty Opinions Recommendation 